University of Nebraska - Lincoln

DigitalCommons@University of Nebraska - Lincoln

To Improve the Academy

Professional and Organizational Development

Network in Higher Education

1997

\title{
Long-Term Patterns in a Mentoring Program for Junior Faculty: Recommendations for Practice
}

Milton D. Cox

Follow this and additional works at: https://digitalcommons.unl.edu/podimproveacad

Part of the Higher Education Administration Commons

Cox, Milton D., "Long-Term Patterns in a Mentoring Program for Junior Faculty: Recommendations for Practice" (1997). To Improve the Academy. 376.

https://digitalcommons.unl.edu/podimproveacad/376

This Article is brought to you for free and open access by the Professional and Organizational Development Network in Higher Education at DigitalCommons@University of Nebraska - Lincoln. It has been accepted for inclusion in To Improve the Academy by an authorized administrator of DigitalCommons@University of Nebraska - Lincoln. 
Cox, M. D. (1997). Long-term petterns in a mentoring program for junior faculty: Recommendations for practice. In D. DeZure (Ed), To Improve the Academy, Vol. 16 (pp. 225268). Stillwater, OK: New Forums Press and the Professional and Organizatiomal Developenent Network in Higher Education Key Words: Mentoring, New Feculty Programs, Faculty Development Programs.

\section{Long-Term Patterns in a Mentoring Program for Junior Faculty: Recommendations for Practice}

\section{Milton D. Cox}

Miami University

Faculty developers believe mentoring programs are beneficial for new and junior faculty. Although there are reports on the early years of these programs, few have existed for more than 15 years. This article reports on a junior faculty program in place for 18 years with the same goals, format, and activities. The endurance of its mentoring component, with continuing support of faculty, former mentors and protégés, and administrators, is a measure of its success. Mentoring patterns relative to gender, mentor repetition, protégés who later mentor, and multidisciplinarity within pairings may be of assistance and encouragement to anyone initiating or continuing a mentoring program. Over 70 recommendations are included.

Mentoring has been used for years in the business world to enable professional development and in academe to foster the scholarly development of apprentices in graduate programs. "Faculty career development, better teaching, quality research, and improved leader- 
ship skills can be positive outcomes of mentoring" (Luna \& Cullen, 1995, p. 71).

Junior faculty are one of the most important resources for colleges and universities. Yet, many of these faculty experience great stress in their initial years (Sorcinelli, 1992). They are a neglected resource (Boice, 1992b), isolated from faculty in other disciplines and often from departmental colleagues. After a brief flurry of attention during faculty orientation, junior faculty may be overlooked by faculty developers and central administrators. What can be done to encourage colleagues and administrators to pay attention to the welfare of these faculty and to help them move from first year to tenure? This is a crucial challenge because the experiences of today's junior faculty will influence the culture and the quality of all aspects of the academy throughout the first half of the 21st century.

\section{Dreams and Realities}

\section{Hopes}

The mentoring of new and junior faculty by experienced faculty is of continuing interest in higher education. Faculty developers have recently expressed a relatively high degree of confidence in the potential of mentoring to improve the quality of teaching in their institutions. For example, Wright and O'Neil $(1994,1995)$ surveyed key instructional development role players at colleges and universities and asked them to rate each of 36 items (activities, policies, and practices) to indicate the confidence the respondent had in the item's potential to improve the quality of teaching on the respondent's campus. Confidence in "mentoring programs and support for new professors" was ranked sixth by respondents in the U.S. (and seventh in Canada).

Kurfiss and Boice (1990) surveyed 330 members of the Professional and Organizational Development Network in Higher Education (one member per campus) to determine current and desired usage of 26 faculty development practices. They reported that only $25 \%$ of the 155 respondents used mentoring programs, which ranked 18 th among the list of 26 practices. However, high interest in mentoring was 
indicated, with $50 \%$ (the second-highest ranking) of those without mentoring programs responding that they planned or desired to implement one.

Hopes for enabling the success of junior faculty through mentoring are not new. As universities grew in size and department communities became dysfumctional, Wise (1967) stated in his essay, Who Teaches the Teachers?, that "colleges must assume a fair portion of the responsibility for inducting new teachers" (p. 88). He further proposed that selected senior faculty be given the responsibility of working with new faculty. Astin and Lee (1967) reported that a survey of deans in U.S. higher education revealed that "most institutions (68\%) have preregistration orientation sessions, but other methods for supervising or training of new faculty are little used" (pp. 307-308).

\section{Paucity of Research}

Boice (1992b) expressed the following concerns about the mentoring of new faculty:

Along with orientations and release time, mentoring is a common goal of campuses with programs for new hires... Mentoring is, moreover, a customary request of new faculty who report feeling isolated and understimulated... With its associations with activities such as teaching and parenting, mentoring seems a minimally necessary component of support programs for new faculty. Yet...mentoring programs are neither well developed nor widely used. A survey of the literature on mentoring indicates that few campuses conduct mentoring in any systematic and demonstrably effective way...Practitioners often imply that it demands too much time. ..that some newcomers neither want nor need it...that pairings afford too many chances for exploitation...or dependency...and that most mentor-protégé pairs will quit meeting...Most advice about establishing programs is conjecture. (pp. 107, 108)

Similarly, Wunsch (1994) noted:

A growing body of literature and research confirms that there are as many theories about mentoring as there are personal experiences of it. There is no universally accepted definition of mentoring and there is a good deal of "magical thinking" about what happens when mentors and mentees do come together. (pp. 1-2) 
Merriam (1987), in a review of 26 mentoring programs, pairing members of various populations, noted that little study had been done on faculty-to-faculty mentoring. Hunt ${ }^{1}$ (1992), in his literature review of mentor outcomes from planned mentoring programs, found "a distinct need for empirical examination of positive and negative mentor outcomes in formal mentoring programs" (p. 43). Hunt detected a change in outcomes between year 1 and year 7 by comparing mentor reports from those years.

\section{Contradictions}

Finding no empirically based advice on the mentoring process, Boice and Turner (Boice, 1990, 1992a, 1992b; Boice \& Turner, 1989) initiated a study of mentoring at a large, comprehensive university. During 1985-87, spontaneous occurrences of informal mentoring of new hires were studied. Only a handful of new faculty established any significant relationship with their mentors, yet those who did fared better than those who did not. The second stage of the research (1987-89) studied formal mentoring pairs (dyads of protégés and mentors in a program that involved weekly meetings of the pairs and monthly meetings of the entire group). Half of the 26 pairs were matched in a traditional way: Mentor and protégé chose each other, mentors were older, and both were in the same department. The other half were paired arbitrarily and across disciplines. Four pairs dropped out of the structured activity of the formal mentoring. Boice reported five important outcomes (1992a, pp. 52-55): (a) Arbitrary pairings and pairings across disciplines worked as well as traditional ones; (b) requiring pairs to meet regularly at the beginning helped ensure pair bonding; (c) pairs working alone displayed narrow mentoring interests, for example, concentrating only on promotion and tenure issues; (d) pairs who participated in the monthly group meetings interacted on a broader variety of topics; and (e) mentors and protégés often waited for each other to indicate a need for help, which resulted in a communication breakdown that inhibited the improvement of teaching. Boice concluded that "mentoring pairs need mentoring" (p. 55).

On the other hand, Holmes (1988) surveyed 44 mentors of new faculty, and the mentors reported that it would not have been helpful 
to attend a seminar on mentoring or to have met with other mentors to share experiences. All 44 of the mentors in the study believed that mentor and protégé should be in the same department. The mentors reported positive experiences, and $96 \%$ indicated that they would serve again.

Other programs have been effective, although taking opposite tacks. For example, Jackson and Simpson (1994) reported that in their successful junior faculty program, "Once the fellow-mentor pair is established, only a minimum amount of structure is imposed on the relationship" (p. 67). On the other hand, Nichols and Amick (1995) have advocated thorough mentor training and developed a series of extensive training modules. Millis (1994) also described a successful program in which mentors receive training in observing teaching and giving constructive feedback.

Luna and Cullen (1995) stated, "Numerous research studies have recommended that same-sex/same-race mentoring relationships be cultivated, if at all possible" (p. 43). Conversely, Boice and Turner (1989) noted that "mentors evidenced the same high level of effectiveness whether they were... [of the] same or opposite sex of the mentee... or [the] same or different ethnicity as the mentee" (p. 126).

Such contradictions may just reflect that a variety of approaches can succeed. All of these programs had beneficial outcomes for both protégés and mentors.

\section{Many Models}

In 1974 the Lilly Endowment established the Lilly Post-Doctoral Teaching Awards Program (now called the Lilly Teaching Fellows Program). The Endowment funds the design and implementation of year-long, campus-wide programs to enhance the teaching of junior faculty at selected research universities (Austin, 1992a, 1992b). Program components include release time, teaching projects, seminars, retreats, and mentoring by senior faculty. In Austin's (1990) survey of 25 former Lilly Teaching Fellows programs in existence during 1974-1985, 12 respondents indicated that mentoring was part of their program, although in four of these programs the mentoring component 
failed. Austin summarized the survey results concerning mentoring as follows:

The component of the Teaching Fellows Program that has varied most greatly across universities is the use of Mentors... where Mentors have been used with some degree of success, the patterns vary considerably...After interviews with past Fellows, Mentors, and Program Directors, I have concluded that no single Mentor model is "the best." Any effective use of the Mentors depends completely on institutional culture, the personality and needs of the particular Fellows and the personality and willingness of the Mentor to get involved in the Program. (p. 82)

\section{No Model}

The findings of these studies are helpful in that they alert practitioners to the realities and complexities of mentoring, evidenced by the variety of approaches and contradictory experiences on different campuses. Shea and Knoedler (1994) reported that at a major research university where the research literature in faculty development was consulted before designing a program for new faculty, it was decided that no mentoring component would be included.

Boice...reported methods he employed to establish successful mentoring partnerships... We have had some experience with mentoring on our campus through the President's Teaching Scholars Program, in which carefully screened professors, whose teaching exemplified excellent practice, were paired with junior faculty who showed promise. In this program, selection has worked from top to bottom, beginning with the identification of master teachers. However, trying to work in reverse, by finding a willing and able mentor for each new faculty member, was deemed undesirable, not solely because good matching is difficult, but also because some mentoring pairs drift apart over time. For example, in the President's Teaching Scholars Program, only 4 of the original 15 pairs are extant. It was apparent from our experience that successful mentoring involved too idiosyncratic a choice to make mentoring mandatory in the new faculty program. (p. 138)

\section{Alternatives and Specializations}

Boice (1992a, pp. 56-60) suggested alternatives to mentoring pairs such as cataloguing, where new faculty compile and revise catalogues of brief descriptions of past, current, and planned activities. 
August (1996) described mentoring committees that were successful. Weimer (1990) encouraged "paper mentoring," that is, mailing newsletters and research articles on teaching to new faculty. In the Wright and O'Neil $(1994,1995)$ survey, however, this practice was ranked 32 out of 36 in its potential to improve teaching. Schoenfeld and Magnan (1994) wrote a book to serve as a "mentor in a manual" for junior faculty.

Some mentoring programs for new faculty have specialized in interesting ways. There are programs designed to mentor only women (Johnsrud, 1994), whereas the long-range goal of the Provost's Faculty Mentoring Program at Eastern Michigan University is to increase the retention of both women faculty and faculty of color (Sayles-Folks \& King, 1994). Retired faculty serve as mentors for new and junior faculty in Temple University's Senior Mentoring Service (Fund for the Improvement of Postsecondary Education, 1991; Rackin, 1992). Seal (1993) provided a summary of information about existing mentoring programs that are designed to engage and vitalize senior faculty. DeBolt (1994) called for a helping community displaying some of the attributes of the preColumbian Iroquois family system. For example, when a newcomer arrived, the rafters of the long house would be extended; in terms of mentoring programs, this means that they would be less formal, with all faculty members in a department involved in and dependent upon cooperative, broad-based development of new colleagues.

In their call for future study, Luna and Cullen (1995) noted:

What works well at one educational institution is not readily known to others interested in developing mentoring programs. Planned, formalized mentoring programs are even rarer, and some of those that exist have failed to determine evaluative outcomes in terms of protégés, mentors, and institutional goals and objectives. Those interested in mentoring research need to identify those programs that have been successful and understand why. (p. v)

\section{Mentoring in the Teaching Scholars Program at Miami University}

This section of the article reports on a junior faculty program that has been in place for 18 years at Miami University and describes some 
of its long-term mentoring patterns and trends that will be of interest and assistance to anyone who is initiating or continuing such a program. The objectives, format, procedures, and activities of this program have not changed much over the 18 years, and the fact that the mentoring component has endured with the continuing support of faculty, former mentors and protégés, and administrators is one measure of its success.

\section{Overview}

Miami University is a state-assisted, doctoral-granting II, residential university in Oxford, Ohio. The enrollment is approximately 16,000 students (including 14,000 undergraduates), with an additional 4,000 students at two nearby, two-year, nonresidential, urban, regional campuses. Miami employs 861 full-time faculty.

The Teaching Scholars Program at Miami University was developed in 1978 and initially funded by the Lilly Endowment's Teaching Fellows Program. The Teaching Scholars Program is a year-long program offering junior faculty in their second through fifth years ${ }^{2}$ the opportunity to pursue their teaching interests and to enhance their teaching abilities through seminars, retreats, national conferences, teaching projects, experienced faculty mentors, and colleagueship with peers from other disciplines. Each year, 8 to 14 junior faculty applicants, representing a variety of disciplines, experiences, and needs, are chosen by an advisory/selection committee. Criteria for selection include commitment to quality teaching, level of interest in the Program, and plans for the award year. Participants in the Teaching Scholars Program receive one-course release time during one semester and modest funding for their teaching projects. A detailed description of the goals, objectives, activities, and outcomes of the Miami Teaching Scholars Program are in Cox $(1994,1995)$.

Mentoring has been an important part of the Teaching Scholars Program since its inception. Over the duration of the Program, 192 teaching scholars and 173 different mentors have been involved in 258 mentoring pairs. (In a given year, a teaching scholar with two mentors will be a member of two pairs, and with three mentors, a member of three pairs.) 


\section{Mentor Selection}

When junior faculty apply in March to participate in the next year's Teaching Scholars Program, they need not have a particular mentor in mind, but they are asked to describe on their application form how they would take advantage of the opportunity to have a mentor. The new junior faculty participants are selected in April. At the day-long opening/closing retreat in May, the outgoing junior faculty participants celebrate and discuss their Program experiences with the incoming group, which "accepts the torch" and begins planning for the next year. One of the retreat sessions is about mentoring and covers strategies for identifying and selecting a mentor, including the issue of whether to select a mentor from within or outside one's department, or from both. This issue is discussed further in the section below on "Multiple Mentors."

New participants select mentors in consultation with the Program director, their department chairs, and colleagues. Mentors are not selected for and assigned to protégés, as in most programs, for example, the Lilly Teaching Fellows Program at the University of Georgia (Jackson \& Simpson, 1994) or the mentoring program for junior faculty women at the University of Hawaii (Johnsrud, 1994). New participants receive a list of over $100 \mathrm{Miami}$ faculty who have volunteered to be resources in over 60 different areas of teaching expertise. They also receive a list of former mentors in the Program along with the names of their protégés, departments, and years served. Former Teaching Scholars and mentors are familiar with the Program, are usually pleased to serve, and bring an informed perspective to the mentoring relationship (some former Teaching Scholars who serve as mentors may have received tenure only recently; they are not "senior" in a traditional sense). The Program director, a Miami faculty member for 31 years, usually can suggest possible mentors for each participant who is looking for someone with specific teaching expertise and sensitivities.

The new Teaching Scholars contact prospective mentors to inquire about their availability and willingness to serve. If there is mutual interest, the new Teaching Scholar often interviews the prospective mentor over lunch. A match usually is made on the first or second try. 
(One junior faculty member enjoyed meeting other faculty so much that he proposed to interview a new mentor prospect each week in lieu of selecting a mentor. The director persuaded him to select a mentor and to continue meeting new faculty.) Prospective mentors who are unfamiliar with the Program discuss mentoring expectations and time commitments with the director or with other colleagues who have served.

\section{Mentoring Activities}

New Teaching Scholars complete their selection of mentors during the first three weeks of the fall semester. Each mentor, new or repeating, receives a letter of welcome (see Appendix) and helpful information on mentoring (including a summary [Cox, 1996] about quick starters [Boice, 1991] and the article, "Women as Mentors: Myths and Commandments" [Sandler, 1993]). The importance of regularly scheduled mentor-protégé meetings is emphasized. Mentors are invited to the triweekly, two-hour seminars for the Teaching Scholars, but to protect the mentors' time, attendance is optional. Each seminar usually is attended by three or four of the 15 to 18 mentors; almost all participate in at least one seminar during the year.

In early October, the mentors, without their protégés, are guests at a luncheon where they discuss mentoring activities, and where mentors with past experience share wisdom. Topics emphasized include the qualities of an effective mentor, interventions on behalf of effective teaching, and various mentoring activities and issues. The discussion often evolves to other teaching issues and the challenges faced by junior faculty.

Mentoring pairs engage in activities such as consulting on the protégé's teaching project and attending each other's classes, campus teaching seminars, and sessions at the Lilly Conference on College Teaching. They meet over lunch or at an exercise session to explore and discuss teaching, learning, and University issues. Small talk is also an important part of the conversation (Boice, 1992b). The extent to which these activities occur depends on the schedules, interests, and personalities of each pair. The Program is flexible and encourages, but does not require, specific activities. 


\section{Rewards}

Mentors view participation in the Teaching Scholars Program as an honor. When the Program started, however, the quality and effectiveness of the Program and its mentoring component were only conjecture. Thus, to encourage mentors during the Program's first three years-a time of Lilly Endowment grant funding-each mentor received a $\$ 150$ honorarium to be used for professional expenses. Several factors contributed to discontinuing this practice: Mentorship gained prestige and provided intangible rewards, such as increased self-esteem and learning; protégés began selecting two or more mentors; the honorarium became an expense that could be cut during the lean years following the expiration of the grant; and less expensive and more meaningful ways of thanking mentors were found.

Each mentor selects a book on teaching as a gift in appreciation of his or her service. Also, mentors and Teaching Scholars are guests at the Lilly Conference on College Teaching in November, at dinner seminars, and at a holiday party in December. Mentors are thanked at a University-wide reception in April and receive a certificate of recognition from the University President and the Provost.

The culture at Miami University places great demands on faculty to be productive scholars, teachers, and practitioners. Mentors are exemplars, the most engaged faculty at the University. The rewards for mentoring in the Program are intrinsic and honorific, but they are not often reflected in salary increases or in promotion and tenure. Two thirds of the mentor-protégé pairings at Miami are outside the mentor's department, away from where rewards are determined. Thus, the effectiveness and quality of mentoring have had to be balanced with the time commitments of the mentors and the half-time Program director. No demands are made for rigorous mentor training, mentor attendance at Program events, and extensive reporting. The importance of mentor training was emphasized in Nichols and Amick (1995) and Millis (1994), but the time required for such careful training would not be well received by potential mentors at Miami and in fact would prevent many from serving. In spite of the need to maintain balance and to accept the trade-offs, the Program has still been successful, as evidenced in the next section. 


\section{Evaluation}

Each year the protégés rate the impact that each component of the Program has had on their development and the extent to which they have achieved the Program's goals. The evaluation also asks openended questions, including one about mentoring. The Program's advisory/selection committee reviews the results of the evaluation and discusses possible modifications of the Program with the Program director.

The 10-person advisory/selection committee is chaired by the Program director and consists of faculty, former mentors and protégés, a department chair, and a student who have rotating three-year terms and represent every division of the University.

During the start-up years of the Program, mentors also were surveyed and carefully interviewed by a program evaluation specialist from another university. Once the value and success of the mentoring component were established and mentors no longer received honoraria, they no longer took part in the formal evaluation of the Program.

\section{Long-Term Patterns, Trends, and Outcomes}

Of the 173 faculty members and administrators who have served as mentors over the existence of the Program, 140 are still at Miami, 19 are retired, 5 are deceased, 7 have moved elsewhere, and 2 were faculty members at other universities when they served as mentors. Only one mentor had emeritus status at Miami when he served. Thus, of the 590 currently tenured faculty members, almost one fourth have served as mentors.

To analyze the long-term mentoring patterns of the Teaching Scholars Program, its 18 years have been divided into 3-year intervals to smooth out annual variations (see Table 1).

\section{Multiple Mentors}

The first trend to note is the increase in the number of mentors and protégé-mentor pairs. To remove the effects of the variation in numbers of protégés, the ratio of protégés to mentors is indicated. During the first three years of the Program, this ratio was just over 1:1, but 
TABLE 1

Number of Junior Faculty Protégés and Their Mentors

In Various Categories

Three-Year Totals and Percentages

\begin{tabular}{|c|c|c|c|c|c|c|c|c|c|c|}
\hline Years & Protogés & Menbrs & \begin{tabular}{c|} 
Protegé \\
Mentor Pairs \\
and Ratios
\end{tabular} & $\begin{array}{l}\text { Mentor in } \\
\text { Same Dept. } \\
\text { as Protgé }\end{array}$ & $\begin{array}{l}\text { Mento } \\
\text { Total }\end{array}$ & $\begin{array}{l}\text { side Dept of } \\
\text { In Cognate } \\
\text { Field }\end{array}$ & $\begin{array}{c}\text { Protigé } \\
\text { In } \\
\text { Noncognate } \\
\text { Field }\end{array}$ & $\begin{array}{l}\text { Protsge } \\
\text { With More } \\
\text { Than One } \\
\text { Mentor }\end{array}$ & $\begin{array}{c}\text { Mentors } \\
\text { Who Were } \\
\text { Former } \\
\text { Protegés }\end{array}$ & $\begin{array}{l}\text { Repeating } \\
\text { Mentors }\end{array}$ \\
\hline $\begin{array}{l}79-80 \\
80-81 \\
81-81 \\
\end{array}$ & 29 & 31 & $\begin{array}{l}31 \\
1: 1.1 \\
\end{array}$ & $\begin{array}{c}1 \\
15 \\
48 \% \\
\end{array}$ & $\begin{array}{l}16 \\
52 \% \\
\end{array}$ & $\begin{array}{l}63 \% \\
10 \\
32 \% \\
\end{array}$ & $\begin{array}{c}37 \% \\
6 \\
20 \% \\
\end{array}$ & $\begin{array}{c}2 \\
7 \% \\
\end{array}$ & 1 & 0 \\
\hline $\begin{array}{l}82-83 \\
83-84 \\
84-85 \\
\end{array}$ & 27 & 36 & $\begin{array}{l}36 \\
1: 1.3 \\
\end{array}$ & $\begin{array}{l}17 \\
47 \% \\
\end{array}$ & $\begin{array}{l}19 \\
53 \% \\
\end{array}$ & $\begin{array}{c}32 \% \\
6 \\
17 \% \\
\end{array}$ & $\begin{array}{l}68 \% \\
13 \\
36 \% \\
\end{array}$ & $\begin{array}{r}9 \\
33 \% \\
\end{array}$ & $\begin{array}{c}7 \\
19 \% \\
\end{array}$ & $\begin{array}{c}9 \\
25 \% \\
\end{array}$ \\
\hline $\begin{array}{l}85-86 \\
86-87 \\
87-88 \\
\end{array}$ & 33 & 44 & $\begin{array}{l}44 \\
1: 1.3 \\
\end{array}$ & $\begin{array}{l}14 \\
32 \% \\
\end{array}$ & $\begin{array}{l}30 \\
68 \% \\
\end{array}$ & $\begin{array}{l}37 \% \\
11 \\
25 \% \\
\end{array}$ & $\begin{array}{l}63 \% \\
19 \\
43 \% \\
\end{array}$ & $\begin{array}{l}10 \\
30 \% \\
\end{array}$ & $\begin{array}{l}11 \\
25 \% \\
\end{array}$ & $\begin{array}{l}15 \\
31 \% \\
\end{array}$ \\
\hline $\begin{array}{l}88-89 \\
89-90 \\
90-91 \\
\end{array}$ & 32 & 41 & $\begin{array}{l}45 \\
1: 1.4 \\
\end{array}$ & $\begin{array}{l}17 \\
38 \% \\
\end{array}$ & $\begin{array}{l}28 \\
62 \% \\
\end{array}$ & $\begin{array}{l}36 \% \\
10 \\
22 \% \\
\end{array}$ & $\begin{array}{l}64 \% \\
18 \\
40 \% \\
\end{array}$ & $\begin{array}{l}10 \\
31 \% \\
\end{array}$ & $\begin{array}{l}13 \\
32 \% \\
\end{array}$ & $\begin{array}{l}11 \\
27 \% \\
\end{array}$ \\
\hline $\begin{array}{l}91.92 \\
92.93 \\
93-94 \\
\end{array}$ & 30 & 42 & $\begin{array}{l}44 \\
1: 1.5\end{array}$ & $\begin{array}{l}15 \\
34 \% \\
\end{array}$ & $\begin{array}{l}29 \\
66 \% \\
\end{array}$ & $\begin{array}{c}21 \% \\
6 \\
14 \% \\
\end{array}$ & $\begin{array}{l}79 \% \\
23 \\
52 \% \\
\end{array}$ & $\begin{array}{l}13 \\
435 \\
\end{array}$ & $\begin{array}{l}12 \\
27 \% \\
\end{array}$ & $\begin{array}{l}19 \\
43 \% \\
\end{array}$ \\
\hline $\begin{array}{l}94-95 \\
95-96 \\
96-97 \\
\end{array}$ & 41 & 58 & $\begin{array}{l}58 \\
1: 1.4 \\
\end{array}$ & $\begin{array}{l}21 \\
36 \% \\
\end{array}$ & $\begin{array}{l}37 \\
64 \% \\
\end{array}$ & $\begin{array}{r}22 \% \\
8 \\
14 \% \\
\end{array}$ & $\begin{array}{l}78 \% \\
29 \\
50 \% \\
\end{array}$ & $\begin{array}{l}17 \\
41 \% \\
\end{array}$ & $\begin{array}{l}14 \\
24 \% \\
\end{array}$ & $\begin{array}{l}25 \\
43 \% \\
\end{array}$ \\
\hline Totals & 192 & 252 & 258 & 98 & 156 & 49 & 107 & 61 & 58 & 79 \\
\hline
\end{tabular}


rose to $1: 1.3$ in the next two 3-year intervals, and then to around 1:1.4 during the last three intervals. These increasing ratios reflect the rising number of Teaching Scholars who chose more than one mentor, from almost none during the first three years, to almost a third during the next three intervals, and to just over $40 \%$ for the last two 3-year intervals. The two (or more) mentors for a protégé do not serve as a committee, but rather form two independent relationships with the protégé.

The ratio of protégés to protégé-mentor pairs was just over 1:1 during all but one of the first seven years of the Program, which reflects the Program leaders' desire to simplify the care and watchful monitoring of the mentor-protégé relationships needed to develop a successful mentoring component. After seven successful years of the Program, Teaching Scholars who were interested in selecting two mentors were encouraged to do so. This enabled a protégé to have one mentor in the same department, often an advantage for political reasons, and one mentor outside the department with whom the protégé could share departmental concerns or weaknesses that could not be revealed to someone within the department. Having a second mentor also provided the protégé with an opportunity to know someone outside the department who perhaps had expertise in a special type of teaching, was influential on a University committee, or was a champion for a common cause. Thirty-three (54\%) of the 61 protégés who selected two mentors chose one mentor from inside and one from outside their department (see Table 2 below). Only 6 (10\%) of the two-mentor protégés chose both from their department. Reasons for doing so were, for example, that the mentors were from different campuses, in different subdisciplines of the department, or of a different gender.

Twelve of the 14 regional campus Teaching Scholars who selected two mentors chose one on the central campus and one on the regional campus. Nine of the 12 chose someone in their department on the central campus to establish a strong departmental connection, which was important because tenure decisions about regional campus faculty are made on the central campus.

In rare cases when a mentor was on leave or engaged in extensive commitments during one of the semesters, the protégé selected a 
TABLE 2

Selections of Departments, Disciplines, and Campuses by Protégés Who Chose More Than One Mentor

D = Mentor in Same Department as Protsgé; C = Mentor in Cognate Discipline of Protégé' N = Mentor in Noncognate Discipline of Protegé;

\begin{tabular}{|c|c|c|c|c|c|c|c|c|c|c|c|c|c|}
\hline Year & DD & $D C$ & DN & CC & CN & NN & DNN & $D C N$ & DNNN & Total & OR & RR & $\infty$ \\
\hline $\begin{array}{l}79-80 \\
80-81 \\
81.82\end{array}$ & 1 & & 1 & & . & & & & & 2 & 1 & & \\
\hline $\begin{array}{l}82-83 \\
83-84 \\
8485 \\
\end{array}$ & 2 & 1 & 2 & & 3 & 1 & & & & 9 & & & \\
\hline $\begin{array}{l}85-86 \\
86-87 \\
87-88 \\
\end{array}$ & & 1 & 3 & 1 & 3 & 1 & 1 & & & 10 & 3 & & 1 \\
\hline $\begin{array}{l}88-89 \\
89-90 \\
90-91 \\
\end{array}$ & & & 4 & & 2 & 2 & & 1 & 1 & 10 & 3 & & \\
\hline $\begin{array}{l}91-92 \\
92-93 \\
93-94\end{array}$ & & 1 & 8 & & 1 & 2 & & 1 & & 13 & 2 & 1 & \\
\hline $\begin{array}{l}9495 \\
95-96 \\
96-97 \\
\end{array}$ & 3 & 1 & 7 & & 3 & 3 & & & & 17 & 3 & & \\
\hline Totals & 6 & 4 & 25 & 1 & 12 & 9 & 1 & 2 & 1 & 61 & 12 & 1 & 1 \\
\hline$\%$ of 61 & $10 \%$ & $7 \%$ & $41 \%$ & , & $20 \%$ & $15 \%$ & & & & & & & \\
\hline
\end{tabular}


second mentor for the other semester. This was the only situation in which two mentors did not interact with their protégé during the same term.

Given the opportunity to choose more than one mentor, only four protégés selected more than two mentors: Three protégés chose three mentors, and one chose four. One year, two protégés chose the same three mentors to enable one joint teaching project.

Although having two mentors might be expected to complicate mentoring for the protégé-for example, a decrease in the frequency of meetings or the intensity of the relationship-this has not been reported. Only once has a protégé selected a second mentor because the first one was not working out. The director of the Program has had little extra work or difficulty because of double mentoring, and additional costs are minor.

\section{Repeating Mentors}

The opportunity for selection of a second mentor was enabled by the willingness of mentors to serve in subsequent years and by the willingness of former protégés to serve. To maintain former Program participants' connection with the Program, each year they are invited to a reunion potluck supper at which the Provost, President, or a campus leader speaks. Program alumni also receive special invitations to campus-wide teaching events sponsored by the Program.

During the first three years of the Program, no mentors repeated (Table 1); the concern was that senior faculty could not be imposed upon to serve twice. Also, the aim at that time was to build a broad base of support for the Program. However, once the Program was in place and positive mentoring experiences emerged, it became clear to the Program director and faculty that mentoring was a valuable experience for the mentor. At that point, Teaching Scholars were not discouraged from selecting mentors who had served before. Thus, the number of mentors who repeated increased from $25 \%$ in the next three 3-year intervals to $43 \%$ in the two most recent 3-year intervals. Over the existence of the Program, 30\% of the 258 protégé-mentor pairs have involved repeating mentors. This is another measure of the success of the Program's mentoring component. 


\section{Former Protégés as Mentors}

Former protégés have become a valuable source of mentors. After the first two years of the program, each year at least one mentor has been a former protégé (Table 1). From the fifth year on (the last 13 years) over one fourth of the mentors have been former protégés; the consistency of this pattern is evidenced in the 3-year intervals over the last 12 years. Successful protégés-those who have attained tenuremake excellent mentors, modeling their mentorship on their own beneficial relationship with a mentor in the past, or bringing to their new relationship the lessons learned from their experiences as protégés.

\section{Disciplinary Connections}

Another mentoring pattern of interest is the change in the disciplinary connection of the mentor-protégé pairings. In the first two 3-year intervals of the Program, almost half of the pairings involved a protége and a mentor in the same department (Table 1). This is a valid strategy for new and developing mentoring programs: A department interested in helping its own junior members should generate willing mentors. However, after the early years of the Program, only one third of the pairings have been in the same department, a consistent pattern exhibited in the 3-year intervals.

Looking at the pairings involving mentors outside the protégés' departments (Table 1), it is noteworthy that in the first three years of the Program, almost two thirds of these pairings were in cognate fields, whereas in the second 3-year interval, two thirds were in noncognate fields, a pattern that continued for the next two 3-year intervals, and increased in the last two 3-year intervals to almost four fifths of the pairings. This pattern reflects the confidence in a maturing and successful mentoring program: Protégés were comfortable selecting a mentor for non-disciplinary reasons, such as tapping the mentor's expertise in a particular area of teaching, creating a safety zone away from the home department, or exploring a different discipline. The option to select more than one mentor has also contributed to the trend of exploring beyond one's department while maintaining a close connection at home. Table 2 indicates that $25(41 \%)$ of the 61 protégés 
who selected two mentors chose one mentor from their department and the other from a noncognate discipline: These 25 two-mentor protégés account for almost one fourth of all 107 noncognate pairs (Table 1). In nine (15\%) of the double selections, both mentors were from noncognate disciplines, usually because these protégés were seeking variety.

\section{Administrators as Mentors}

Of the $\mathbf{4 5}$ departments at Miami, only four have had no mentors in the Program, and only one of these departments has also had no protégés. Eleven departments are now chaired by current or former mentors, but only one chair is currently mentoring a protégé in his own department, which has happened only four times in the history of the Program. This practice is not encouraged, because a certain openness and safety in the relationship can be lost. However, in two of the cases the Teaching Scholar selected a second mentor, and, in all four pairings, the experience worked out satisfactorily. In addition to the 11 current department chairs, 23 other mentors have served as chairs. Almost 20\% of all mentors are or have been department chairs.

Two deans have been mentors while serving as deans, one for a protégé in his division and one not. A former provost and a former university president also have served as mentors. Eleven mentors are or have been associate provosts or associate or assistant deans. Seven mentors have come from academic support units: four from applied technologies, and one each from international programs, learning assistance, and budget analysis. Of the 173 mentors, $24 \%$ have served as administrators (including department chairs) before, during, or after their mentorship.

\section{Gender Patterns}

Currently $73 \%$ of the Miami University faculty is male, and just $27 \%$ of all tenured and tenure-track faculty are women. Yet, genderrelated patterns (see Table 3 below) reveal an overall balance between the numbers of male and female junior faculty in the Teaching Scholars Program. After the first 3-year interval, in which the ratio of males to females was 3:2, and in the next two 3-year intervals in which 
TABLE 3

Gender Patterns in Mentoring of the Teaching Scholar Protégés $M=$ Male,$F=$ Female, and $T=$ Total

\begin{tabular}{|c|c|c|c|c|c|c|c|c|c|c|c|c|c|c|c|c|c|}
\hline \multirow[b]{2}{*}{ Years } & \multicolumn{3}{|c|}{ Protugés } & \multicolumn{3}{|c|}{ Mentors } & \multicolumn{11}{|c|}{$\begin{array}{l}\text { Number of Protegess of the Indicated Gender (Top Letter) Selecting Mentors of the Indicabed } \\
\text { Gender (Bottom Letterfs) }\end{array}$} \\
\hline & $M$ & $\mathbf{F}$ & $T$ & $M$ & $F$ & $T$ & $\begin{array}{c}M \\
M\end{array}$ & $\stackrel{M}{F}$ & $\begin{array}{l}\mathbf{F} \\
\mathbf{F}\end{array}$ & $\begin{array}{l}\mathrm{F} \\
\mathrm{M}\end{array}$ & $\begin{array}{c}M \\
M M\end{array}$ & $\begin{array}{c}M \\
M F\end{array}$ & $\begin{array}{c}M \\
F F\end{array}$ & $\begin{array}{l}\text { F } \\
\text { FF }\end{array}$ & $\begin{array}{c}\mathrm{F} \\
\mathrm{MF}\end{array}$ & $\begin{array}{c}\mathbf{F} \\
M M\end{array}$ & - \\
\hline $\begin{array}{l}79-80 \\
80-81 \\
81-82 \\
\end{array}$ & 18 & 11 & 29 & 26 & 5 & 31 & 16 & & 3 & 8 & 2 & & & & & & \\
\hline $\begin{array}{l}82.83 \\
83-84 \\
8485\end{array}$ & 13 & 14 & 27 & 30 & 6 & 36 & 8 & & 2 & 8 & 5 & & & 2 & & 2 & \\
\hline $\begin{array}{l}85-86 \\
86-87 \\
87-88 \\
\end{array}$ & 17 & 16 & 33 & 32 & 12 & 44 & 12 & 1 & 2 & 8 & 3 & 1 & . & & 5 & & 1* \\
\hline $\begin{array}{l}88-89 \\
89-90 \\
90-91\end{array}$ & 14 & 18 & 32 & 29 & 12 & 41 & 11 & & 5 & 6 & 2 & 1 & & 1 & 3 & 1 & - \\
\hline $\begin{array}{l}91.92 \\
92.93 \\
93-94 \\
\end{array}$ & 14 & 16 & 30 & 31 & 11 & 42 & 8 & & 5 & 4 & 5 & & & 1 & 4 & 2 & - \\
\hline $\begin{array}{l}9495 \\
95-96 \\
96-97 \\
\end{array}$ & 16 & 25 & 41 & 35 & 23 & 58 & 10 & & 11 & 3 & 4 & 1 & 1 & 2 & 5 & 4 & \\
\hline Totals & 92 & 100 & 192 & 186 & 69 & 252 & 65 & 1 & 28 & 37 & 21 & 3 & 1 & 6 & 17 & 9 & 4 \\
\hline
\end{tabular}




\begin{tabular}{|l|c|c|c|}
\hline \multicolumn{10}{|c|}{ TABLE 3, Continued } \\
\hline \multicolumn{10}{|c|}{ Gender Patterns in Mentoring of the Teaching Scholar Protégés } \\
$M=$ Male, F = Female, and T = Total \\
\hline
\end{tabular}


there was a balance, the number of females has exceeded the number of males, with the ratio reversing to $2: 3$ in the most recent interval. Thus, the Program has gained a reputation for providing colleagueship and support for women junior faculty.

On the other hand, the overall ratio of male to female mentors is $3: 1$, reflecting the lower percentage of women on the faculty as a whole. As the number of women faculty hired has increased, the percentage of female mentors has increased, from $16 \%$ during the first two 3-year intervals, to over $25 \%$ during the next three intervals, and to $43 \%$ in the most recent 3-year interval. In fact, in 1996-97, the number of male and female mentors was equal for the first time.

The number of females who choose only one mentor, a female, has increased fourfold, whereas the number of women who choose a male mentor has decreased correspondingly. The number of male protégés selecting male mentors has held constant. Over the existence of the Program, only one male has selected a female as his only mentor, and only four males have selected both male and female mentors. In 1996-97, for the first time, a male selected two females as his two mentors. The mentor who has served most often-eight times-is female; the three who have served five times are male; and two of the five serving four times have been female.

There has been little discussion among Program participants or advisory committee members about the need to attain certain gender patterns in mentoring. Mentor selection has been driven only by the protégés' wishes and the availability of the types of mentors they were seeking.

\section{Race}

Although efforts have been made to recruit and retain a racially diverse faculty, only $3 \%$ of the Miami faculty is African American and 3.6\% is Asian. Reflecting these percentages, only seven (3.6\%) African Americans and seven Asians have been protégés in the Program. Given that the protégés select their mentors, it is interesting to note that only one of the seven African American protégés selected an African American mentor, and only two of eight Asians chose Asian or Asian American mentors. Moreover, only one third of all 
protégés in the Program selected mentors in their departments, but all African Americans selected mentors in their department. And finally, whereas half of all protégés selected mentors in noncognate departments, Asians selected none in noncognate departments.

Although contributing to the retention of junior faculty from first year to tenure is an objective of the Program, the retention of minorities has not been the focus of special Program efforts; other University programs have taken that role. Of the seven African American protégés, one is tenured, two are currently probationary, three moved to other careers before the tenure decision, and one was refused tenure. Of the Asians, three of the seven are tenured, three are currently probationary, and one moved to another university before the tenure decision.

\section{Program Effectiveness}

The effectiveness of the components of the Teaching Scholars Program has been rated by the protégés using the same instrument since 1981-82 (see Table 4 below). The protégés report the degree of impact of seven Program components, on a scale from 1 (very weak impact) to 10 (very strong impact). Ranked clearly first, with an impact of 8.9, was "the colleagueship and learning from the other Teaching Scholars." Four other program components clustered next in the 8.3 8.0 range, with the mentor relationship at 8.0. The mentoring aspect of the Program, although ranked only fifth, has had a positive impact on the protégés, as evidenced by the 8.0 overall rating it has earned over the years. Each year at least one protégé has ranked highest the impact of the mentoring component. The Teaching Scholars also reported a Program impact of 7.8 on their effectiveness as a teacher.

Another interesting note about the Program as a whole is that its junior faculty participants are tenured at a rate significantly higher than that of junior faculty who have not participated (Cox, 1995). Of the Program's total of 192 Teaching Scholars, 140 (73\%) are currently (1996-97) at Miami. One hundred six (55\%) have been tenured, 96 of whom are still at Miami; 43 of the 192 (22\%) are currently probationary tenure-track faculty; and $40(21 \%)$ have left without tenure. 
TABLE 4

Protégé Ratings of the Components of the Teaching Scholars Program

Summary of responses to the question, "How would you rate the impact of each of the following components of the Teaching Scholars Program on you?" "1" indicates a very weak impact, and "10" indicatos a very strong impact.

\begin{tabular}{|c|c|c|c|c|c|c|c|}
\hline \multicolumn{8}{|c|}{ Number in parentheses is ranking, and number on second line is mean for that component } \\
\hline$\cdot$ & Components & $\begin{array}{l}81-82 \\
\text { (1 year) }\end{array}$ & $\begin{array}{l}82-83 \\
83-84 \\
8485 \\
\end{array}$ & $\begin{array}{l}85-86 \\
86-87 \\
87-88 \\
\end{array}$ & $\begin{array}{l}88-89 \\
89-90 \\
90-91\end{array}$ & $\begin{array}{l}91-92 \\
92-93 \\
93.94 \\
\end{array}$ & $\begin{array}{r}9495 \\
95-96 \\
\text { (2 yoars }\end{array}$ \\
\hline $\begin{array}{l}\text { (1) } \\
8.9\end{array}$ & The colleagueship and learning from the other Teaching Scholars & $\begin{array}{l}\text { (3) } \\
8.8\end{array}$ & $\begin{array}{l}\text { (3) } \\
8.6\end{array}$ & $\begin{array}{l}(4) \\
8.2\end{array}$ & $\begin{array}{l}(1) \\
9.6\end{array}$ & $\begin{array}{l}\text { (1) } \\
8.9\end{array}$ & $\begin{array}{l}\text { (1) } \\
9.0\end{array}$ \\
\hline $\begin{array}{l}\text { (2) } \\
8.3\end{array}$ & The retreats and conferences & $\begin{array}{l}\text { (5) } \\
7.7 \\
\end{array}$ & $\begin{array}{l}\text { (5) } \\
7.9\end{array}$ & $\begin{array}{l}\text { (1) } \\
8.7 \\
\end{array}$ & $\begin{array}{l}\text { (2) } \\
8.5 \\
\end{array}$ & $\begin{array}{l}\text { (2) } \\
8.4\end{array}$ & $\begin{array}{l}\text { (3) } \\
8.0 \\
\end{array}$ \\
\hline $\begin{array}{l}\text { (3) } \\
8.2\end{array}$ & The teaching project & $\begin{array}{l}\text { (1) } \\
9.0 \\
\end{array}$ & $\begin{array}{l}\text { (1) } \\
8.7\end{array}$ & $\begin{array}{l}(6) \\
7.6 \\
\end{array}$ & $\begin{array}{l}\text { (2) } \\
8.5\end{array}$ & $\begin{array}{l}\text { (4) } \\
7.9\end{array}$ & $\begin{array}{l}(4) \\
7.9\end{array}$ \\
\hline $\begin{array}{l}(4) \\
8 / 1\end{array}$ & Release Time & $\begin{array}{l}\text { (1) } \\
9.0\end{array}$ & $\begin{array}{l}\text { (4) } \\
8.5\end{array}$ & $\begin{array}{l}\text { (2) } \\
8.3\end{array}$ & $\begin{array}{l}\text { (5) } \\
7.8\end{array}$ & $\begin{array}{l}\text { (3) } \\
8.2\end{array}$ & $\begin{array}{l}(5) \\
7.3\end{array}$ \\
\hline $\begin{array}{l}\text { (5) } \\
8.0\end{array}$ & The mentor rolationship & $\begin{array}{l}\text { (4) } \\
8.7\end{array}$ & $\begin{array}{l}\text { (1) } \\
8.7\end{array}$ & $\begin{array}{l}\text { (2) } \\
8.3\end{array}$ & $\begin{array}{l}\text { (6) } \\
7.4\end{array}$ & $\begin{array}{l}6) \\
7.4\end{array}$ & $\begin{array}{l}\text { (2) } \\
8.2\end{array}$ \\
\hline $\begin{array}{l}\text { (6) } \\
7.5 \\
\end{array}$ & Sominars & $\begin{array}{l}(6) \\
7.3 \\
\end{array}$ & $\begin{array}{l}\text { (6) } \\
7.5\end{array}$ & $\begin{array}{l}(7) \\
7.2\end{array}$ & $\begin{array}{l}(4) \\
7.9\end{array}$ & $\begin{array}{l}\text { (4) } \\
7.9\end{array}$ & $\begin{array}{l}\text { (6) } \\
7.2\end{array}$ \\
\hline $\begin{array}{l}(7) \\
6.9 \\
\end{array}$ & Observation of mentor's or others' classes & $\begin{array}{l}\text { (7) } \\
6.3 \\
\end{array}$ & $\begin{array}{l}\text { (7) } \\
7.3\end{array}$ & $\begin{array}{l}(5) \\
8.0 \\
\end{array}$ & $\begin{array}{l}(7) \\
6.2\end{array}$ & $\begin{array}{l}(7) \\
6.5\end{array}$ & $\begin{array}{l}(7) \\
6.8\end{array}$ \\
\hline 8.0 & Overall mean for cohort & 8.1 & 8.2 & 8.0 & 8.0 & 7.9 & 7.8 \\
\hline
\end{tabular}


Former Teaching Scholars currently chair 8 of Miami's 45 departments; five of these chairs have also served as mentors.

Another measure of success is that the Program received the 1994 Hesburgh Award, given to the faculty development program judged best in the U.S. in fulfilling the three award criteria: significance of the program to higher education; appropriate program rationale; and successful results and impact on undergraduate teaching and learning.

\section{Recommendations}

The recommendations below are addressed to anyone who is designing or continuing a mentoring program for junior faculty. The recommendations are based upon 18 years of experience in directing the Teaching Scholars Program and on the outcomes of that Program. Some of the recommendations confirm or contradict the findings and practices of others, but the recommendations based on long-term patterns and trends are new and offer a forecast about the long-term performance of other programs. As always, one's own campus culture must be carefully considered when employing suggestions from a different campus.

\section{Program Design, Organization, and Expectations}

- Program planners should explore a variety of successful approaches discussed in the literature and then adopt what best fits their campus culture.

- Mentoring should not be the sole purpose of a program but rather an important component of a program that has additional objectives and a broader focus, for example, enhancing the protégé's teaching effectiveness, publication productivity, or comfort in the university community.

- The goals and objectives of the mentoring component of the program must be clear.

- The program must receive endorsement and support from students, junior and senior faculty, department chairs, deans, and central administrators, including the president and academic vice president. The student and university senates (or their equivalents) should approve. 
- A campus-wide mentoring program must have a director or coordinator, preferably a respected and seasoned faculty member or administrator with several years' experience on the program's campus.

- A faculty coordinator should receive at least one course release time and a professional expense account, including membership in POD and attendance at its national conference.

- The program should be campus-wide, spanning departments, divisions, and professional schools. Many valuable pairings are made across divisions.

- The program should be housed in a central and respected office such as the teaching and learning or faculty development center, or in the office of the academic vice president or president.

- The program should have an advisory committee that includes representatives from former protégés and mentors, from faculty inside and outside the program, and from a variety of disciplines. A department chair and a student should also be members. Rotating three-year memberships should be established to ensure both continuity and fresh perspectives.

- Secretarial support is a must to assist the director in coordinating communications, arranging meetings, providing publicity, maintaining records, coordinating thank-you activities, and so forth.

- Temper expectations that mentoring pairs will remain active after their program year. Junior faculty will establish friendships with peers, and other demands and commitments will draw protégé and mentor to different interests.

\section{Identifying Prospective Mentors}

\section{Planning Stage}

- Contact seasoned faculty and department chairs to elicit their ideas and support for the proposed program.

\section{Start-Up Years}

- To build a broad pool of mentors and to spread participation across campus, discourage protégés or program leaders from inviting 
mentors to repeat during at least the first three years of the program. However, make an exception in cases where a new protégé and a former mentor have a strong wish to pair.

- When a junior faculty member is difficult to pair, ask the protégé's department chair to suggest possibilities for pairings within the department.

\section{All Stages}

- Survey all faculty to identify those who are willing to share their expertise with others on campus. For example, if enhanced teaching effectiveness is an objective of the program, faculty could volunteer to be on a teaching resource list, indicating their willingness to share teaching experiences and resources, on, for example, case studies, cooperative learning, feminist pedagogy, the Internet, and so on.

- Provide the teaching resource list to the entire campus as well as to junior faculty who are looking for a mentor with some particular expertise.

- Seasoned faculty need not have a monopoly on mentoring. When appropriate, involve newly tenured faculty, and in unusual circumstances, even untenured faculty, who can be excellent mentors. Mentors need to be good teachers, but not necessarily have a long track record or be award winners (Sorcinelli, 1995).

- Current and former administrators-as well as faculty who show promise and interest in administration-should be encouraged to serve as mentors. Administrators bring experience from "both sides" and have a commitment to service.

- Consider key academic support personnel (for example, in technology) as mentors to enable a teaching project. However, if the academic support person has no experience as a faculty member, an additional faculty mentor is recommended.

\section{Mentor Training}

Mentors need some training, but the literature is contradictory about how much. More training is needed when programs are starting up. Certain basic issues must be covered for all first-time mentors. For 
example, mentors must avoid comments about how easy it was to get tenure "back then."

- Mentor training should be tailored to the faculty culture on one's campus.

- The time devoted to training must be balanced with other faculty demands and priorities. Successful mentoring programs exist where mentor training is not structured or extensive.

- Both protégés and mentors need orientation to mentoring. The orientation can be effective whether it is a separate or joint, one-time or monthly, informal or formal activity.

- Mentors and protégés should be familiarized with the qualities of junior faculty who are "quick starters" (Boice, 1991) and be encouraged to develop these qualities.

\section{Matching Mentors and Protégés}

In most junior faculty mentoring programs described in the literature, the program director matches junior faculty with faculty in a predetermined pool of mentors. However, there are certain advantages when the junior faculty member makes the selection: The protégé feels a sense of ownership of the decision; the mentor may feel a stronger connection to a protégé who has made a special effort to select her or him; the process of investigating and interviewing potential mentors broadens the exposure of the junior faculty member to other faculty; interviewing offers both members of the potential pair a more careful look at the possible relationship and minimizes the disappointment when a connection is not made; and finally, placing this responsibility with the junior faculty eases the program director's role in the selection process.

- Junior faculty should select their own mentors, assuming that a list of qualifications and interests of experienced faculty and consultation with the program director are available.

- If openings to participate in the program are limited, the junior faculty applicants should be required to indicate on their application forms how the mentoring experience would aid their accomplishment of program and personal objectives. 
- At the end of each program year, the outgoing group of junior faculty participants should meet with the incoming group to share wisdom and to answer questions before the new participants select their mentors. This discussion of mentoring should include valuable advice, exploration of alternatives, and interesting stories for the new group.

\section{Mentor-Protégé Activities}

Boice (1992b) noted, "By their own admission, pairs showed a medley of mentoring styles; the more I saw of mentoring, the less confident I felt in prescribing how it should be done" (p. 112).

- Be flexible, and allow for creative mentoring.

Activities may include both scholarly and social ventures, for example, consulting on the protégé's teaching project; attending each other's classes (if schedules conflict, discussing videotapes of teaching is an option); exchanging small group instructional diagnosis (SGID) visits; attending program seminars and events; engaging in small talk; and discussing issues concerning teaching, learning, politics, tenure, publishing, and so forth over coffee, lunch, exercising, golf, or other relaxing activities.

- The mentor-protégé pair should engage in a variety of activities, but the above list should be viewed as a menu, not a checklist of requirements. Pairs should select activities that are of mutual interest, fit both schedules, and generate discussion.

- Prompt pairs to meet regularly; left alone, pairs tend to decrease their contact under the press of other demands.

- Encourage pairs to keep a log or journal that can serve as a reference when the protége is summarizing activities for the mid-year and final reports.

\section{Protégé Group Activities}

Tenure uncertainties and the isolation imposed by departmental boundaries are two commonalities that bond junior faculty groups.

- The group of protégés should meet at least monthly for seminars, which should include time for socializing. 
- During group seminars, protégés occasionally need to vent their frustrations about the tenure process. Others should listen sympathetically and suggest ways to deal with the stress (Sorcinelli, 1992).

- Do not let occasional laments distract from the positive aspects of colleagueship and the excitement about teaching and learning.

\section{Rewards}

Burgess (1994) wrote:

They...resisted the formal use of the terms mentor and mentee... The low key phrases of helping each other and working together were preferred. At all costs any association with expert status is avoided - the "tall poppy" syndrome continues to be prevalent in Australia. (p. 70)

"Across campuses, mentors indicate that they not only give assistance but receive benefits significant to their own personal and professional growth" (Sorcinelli, 1995, p. 183).

\section{The Start-Up Years}

- Take into account the culture and traditions of the campus, how rewards are handled in related programs, the availability of mentors, the program's budget, issues of elitism, and so on.

- When it fits the culture, each mentor should receive a modest honorarium to be used for professional expenses and should also receive recognition at thank-you ceremonies.

\section{Later Years}

- In a low-budget program, recognize that intrinsic awards will be sufficient.

- Once the value and prestige of the program have been established, make rewards more honorific in nature, for example, a complimentary copy of a book of the mentor's choice, honored guest status at program dinners and retreats, a certificate of appreciation from the institution's president and provost, and so forth. "Thank yous" are essential. 


\section{Evaluation of Program Effectiveness}

- During the start-up years, both protégés and mentors should evaluate their experiences, the impact of the program on their development, and the extent to which they have achieved the program's objectives.

- After the start-up years, when rewards for mentors have become mostly honorific, the participation of mentors in program evaluation should be balanced with their time commitments and willingness to serve.

- For the protégés, require mid-year and final reports that assess the effectiveness of the program components and the achievement of program objectives. Summarize the reports for the program's advisory committee and for administrators.

- Determine ways to measure value-added qualities, for example, a comparison of a protégé's pre and postprogram syllabi.

- Each program event and retreat should be evaluated.

- Maintain records of what protégés and mentors do after participation in the program, for example, which protégés are granted tenure, which become department chairs, and so on.

- A strong connection between pairs after the program year is a highly desirable program outcome. However, it is a difficult objective to achieve unless resources are committed to ongoing activities for past pairs. Consider this item carefully before adding it to the criteria for program success.

\section{Long-Term Patterns and Trends}

\section{Former Protégés and Mentors}

After a mentoring program has gone through its start-up years and evolved into a successful program, there will be an experienced group of potential mentors made up of former protégés who are now tenured and an experienced group of mentors who are willing to serve again. This population will grow as the program continues; an ongoing mentoring program will never run out of mentors.

- In long-range planning, consider that after five or six years, $25 \%$ of the mentors who serve in a given year will be former protégés 
and $25 \%$ will be repeat mentors. As the program continues into a second decade, the number of repeat mentors in a given year may increase to $40 \%$.

- Provide opportunities for former mentors and protégés to come together each year, for example, at a reunion potluck supper. This will keep them in touch with the program.

- Consider a program newsletter to help keep the community alive.

- For junior faculty who are selecting mentors, provide a list of former protégés and mentors indicating the years they served and their disciplines and teaching interests.

\section{Multiple Mentors}

One fortuitous result of having an increasing number of potential mentors is the opportunity for a protégé to select two mentors. A junior faculty member should choose two mentors when the following opportunities appear advantageous and comfortable: working with one mentor inside the protégé's department and one outside; having one mentor on the protégé's regional campus and one on the central campus; interacting with mentors in two different but important subdisciplines in the protégé's department (there may be political reasons for doing so); developing a teaching project or addressing a concern that needs two distinct areas of expertise; exploring interdisciplinarity or diversity; and meeting and working with a variety of people.

- After a program's start-up years, consider multiple mentoring when a broad base of mentors has been established across several disciplines and when several former protégés have earned tenure.

- Emphasize to junior faculty that having two mentors is an option.

- Structure double mentoring for a protégé as two separate mentoring pairs, a mentoring committee, or some combination of both.

- A junior faculty member probably should not select two mentors if he or she does not consider the mentoring component of the program important or if the logistics and time commitment of working with two mentors seems too great an investment.

- In planning ahead, take into account that once double mentoring is encouraged, probably one third of the junior faculty in the program will select two mentors. In the second decade of the 
program, this may increase to $40 \%$. Also, half of the protégés who choose two mentors will select one from inside the department and one from outside.

- Do not divide double mentoring into single mentoring over two different semesters unless double mentoring solves the problem of having one mentor who is on leave or overwhelmed one of the semesters.

- Managing double mentoring adds little work for the director when the protégés make the selections and do the asking.

- Double mentoring adds little expense to the budget when rewards are modest, for example books and recognition.

\section{Inside or Outside the Department?}

Boice and Turner (1989) noted, "curiously, those pairs who were matched across traditional boundaries such as discipline concluded that opposites work best together; similarly, those paired within traditional bounds felt certain that similars work best" (p. 127).

- During the start-up years, a conservative strategy involves consultation with department chairs about mentor selection. This will probably result in having at least half of the mentors from the same department as the protégé.

- After the start-up years, because of confidence in the effectiveness of the program, expect that two thirds of the mentors will be selected from outside the protégé's department.

- Encourage junior faculty to consider and discuss the inside/outside choice and to elect the option with which they feel most comfortable. If double mentoring is available, this enables junior faculty to choose both options.

\section{Disciplinary Connections}

The richness of multidisciplinarity will inform program seminars (for example, team teaching across disciplines, assessment in liberal education, etc.).

- Include programming reflecting the fact that $40 \%$ to $50 \%$ of all mentoring pairs in a given year may involve noncognate disciplines, with two thirds of the protégés who select a mentor outside 
the department choosing a mentor in a noncognate field. For example, half of the mentor-protégé classroom visitations could involve nonexpert observers.

\section{Gender}

Johnsrud (1994) noted:

Women faculty who experience immediate attention to their adjustment and professional growth are more likely to want to stay after they are hired. To be effective, a mentoring program must meet the needs of individual faculty women, but also be part of a general support system. (p. 61)

Finding enough women mentors may be a challenge. Although the percentage of seasoned women faculty is growing on most campuses, it is considerably below the percentage of experienced male faculty.

- Any mentoring program must support and provide a warm climate for women faculty.

- Mentoring programs that involve men and women junior faculty should attempt to achieve gender balance.

- Seminar programming should include topics about differences, and such seminars should balance perspectives. For example, differences in student intellectual development should include the theories of both Perry and Belenky et al., or a seminar on the evaluation of teaching should address the special concerns of women faculty.

- Opportunities and patterns should be discussed with protégés before they select mentors.

- Both women and men junior faculty who are interested in gender differences should consider double mentoring, with one mentor a female and one a male. For example, only about $10 \%$ of the women and $2 \%$ of the men may take advantage of this opportunity. Current trends at Miami indicate that around $70 \%$ of today's junior faculty women will choose a female mentor, whereas only around $10 \%$ of the men will select a female mentor.

- Encourage recently tenured women faculty to serve; most are sensitive to the inequities in academe and are eager to mentor new 
colleagues, as evidenced by the rapid increase in the percentage of women mentors at Miami University.

- Realize that women faculty will be making a commitment to mentoring which is disproportionate to that of their male colleagues; celebrate and honor this giving.

\section{Race}

"We were not surprised to find that although white male faculty members were readily brought into the informal mentoring network, women faculty and faculty of color were not" (Sayles-Folks \& King, 1994, p. 276). Although information and research on same-race mentoring is scarce, it appears that same-race mentors exhibit cultural sensitivity and make efforts to focus on the similarities rather than differences of the pair (Luna \& Cullen, 1995). "Some research has shown that cross-race mentoring relationships have not been successful because of personal and organizational barriers" (p. 59).

- Understanding differences should be a clearly stated objective of the program, and recruiting information should mention this.

- Minority junior faculty who are unfamiliar with the culture of their new institution should receive advice about mentoring beyond that given other participants. For example, before mentor selection, the program director should alert African American junior faculty to cross-race mentor concerns.

- Minority faculty who need to build their research and publications should consider selecting a successful senior researcher who exhibits cultural sensitivity and who is willing to do the special mentoring needed to achieve this goal.

- Mentors should know or learn about the special traditions and culture of their protégés.

\section{Closing Thoughts}

When we teach, as parents or faculty or coaches or developers, there is a gap, a tension, between our high expectations-where we want our students to be at the end of the learning period-and where they are at the moment. Effective teachers blend challenges-exams, papers, performances, internships, publications-with feedback and 
support. Mentoring is an important form of support. As faculty developers, we must provide a bridge for our stressed junior faculty to help them journey from first year to tenure. A mentoring program can be a key part of the bridge structure, and our seasoned faculty can serve as guides for the crossing. And, of course, our protégés often become inspirations and guides for us.

In reading the literature, we find that the mere establishment of a structured mentoring program creates good will for both junior faculty and mentors, and that this in turn brings encouragement and appreciation to many parts of the campus. This appears to happen whether the mentor is in the same or a different department, of the same or a different gender, or formally or informally trained. These feelings may seem like "magical thinking" or "conjecture," but most junior faculty and mentors who participate in any kind of structured mentoring program feel enriched in several ways. This phenomenon must be studied more carefully across colleges and universities.

In this article I have shared ways that the bridge and its crossing can be made safer, smoother, and more productive, and how, over the years, the journey can become better-more interesting, more complex in a positive way, and populated with former travelers and guides who are pleased to return to help newcomers along the way.

\section{Footnotes}

${ }^{1}$ David Hunt was a protégé in Miami's Teaching Scholars Program in 1981-82, and his teaching project involved a study of mentoring.

${ }^{2}$ First-year faculty are not eligible for the Teaching Scholars Program because the Program's designers believed that a proféssor's initial year is necessarily focused on adjusting to and getting comfortable with the department. (Some divisions and departments at Miami have an internal mentoring program for first-year faculty. When surveyed in 1994, nearly $75 \%$ of the responding departments indicated that they had a mentoring program; however, half indicated that the chair was the only mentor. In addition, half reported that their programs were informal, mainly because new hires were infrequent.). 


\section{References}

Astin, A. W., \& Lee, C. B. T. (1967). Current practices in the evaluntion and training of college teachers. In C. B. T. Lee (Bd.), Improving college teaching (pp. 296-311). Washington, DC: American Council on Education.

August, J. R. (1996). Mentor committees enhance early faculty development. Intermational Mentoring Association Diversity in Mentoring Proceedings (pp. 11-20). Kalamazoo, MI: Western Michigan University.

Austin, A. E. (1990). To leave an indelible mark: Encouraging good reaching in research universities through faculty development. A study of the Lilly Endowment's Teaching Fellows Program 1974-1988. Nashville, TN: Vanderbilt University, Peabody College.

Austin, A. E. (1992a). Supporting junior faculty through a teaching fellows program. In M. D. Sorcinelli \& A. E. Austin (Eds.), Developing new and junior faculty (New Directions for Teaching and Learning No. 50) (pp. 73-86). San Francisco: JosseyBass.

Austin, A. E. (1992b). Supporting the professor as teacher: The Lilly teaching fellows program. The Review of Higher Education, 16, 85-106.

Boice, R. (1990). Mentoring new faculty: A program for implementation. The Journal of Staff, Program, and Organization Development, 8, 143-160.

Boice, R. (1991). Quick starters: New faculty who succeed. In M. Theall \& J. Franklin (Eds.), Effective practices for improving teaching (New Directions for Teaching and Learning No. 48) (pp. 111-121). San Francisco: Jossey-Bass.

Boice, R. (1992a). Lessons learned about mentoring. In M. D. Sorcinelli \& A. E. Austin (Eds.), Developing new and junior faculty (New Directions for Teaching and Learning: No. 50) (pp. 51-61). San Francisco: Jossey-Bass.

Boice, R. (1992b). The new faculty member: Supporting and fostering professional development. San Francisco: Jossey-Bass.

Boice, R., \& Turner, J. L. (1989). The FIPSE-CSULB Mentoring Project for New Faculty. In S. Kahn (Ed.), To Improve the Academy, Vol. 8. (pp. 117-129). Stillwater, OK: New Forums Press and the Professional and Organizational Development Network in Higher Education.

Burgess, Z. (1994). Mentoring of academic staff: An experiment in mentoring diversity. International Mentoring Association Diversity in Mentoring Proceedings (pp. 6171). Kalamazoo, MI: Westem Michigan University.

Cox, M. D. (1994). Reclaiming teaching excellence: Miami University's Teaching Scholars Program. In E. Wadsworth (Ed.), To Improve the Academy, Vol. 13. (pp.79-96). Stillwater, OK: New Forums Press and the Professional and Organizational Development Network in Higher Education.

Cox, M. D. (1995). The development of new and junior faculty. In W. A. Wright \& Associates (Eds.), Teaching improvement practices: Successful strategies for higher education (pp. 283-310). Bolton, MA: Anker. 
Cox, M. D. (1996). Getting off to a good start: "Best" teaching behaviors and Miami teaching support systems. (Handout for new faculty, available from the Office for the Advancement of Scholarship and Teaching, Minmi University, Oxford, OH 45056).

DeBolt, G. P. (1994). A family approach to mentoring new teachers: Lescons from Native Americans. International Mentoring Association Diversity in Mentoring Proceedings (pp. 93-103). Kalamazoo, MI: Western Michigan University.

Fund for the Improvement of Postsecondary Education. (1991). The senior mentoring service: Sustaining and strengthening a teaching culture. Washington, DC: Author.

Holmes, S. K. (1988). New faculty mentoring: Benefits to the mentor. The Journal of Staff, Program, and Organization Development, 6, 17-20.

Hunt, D. (1992). A longitudinal study of mentor outcomes. Mentoring International, 6, $41-47$.

Jackson, W. K., \& Simpson, R. D. (1994). Mentoring new faculty for teaching and research. In M. A. Wunsch (Ed.), Mentoring revisited: Making an impact on individuals and institutions (New Directions for Teaching and Learning No. 57) (pp. 65-72). San Francisco: Jossey-Bass.

Johnsrud, L. K. (1994). Enabling the success of junior faculty women through mentoring. In M. A. Wunsch (Ed.), Mentoring revisited: Making an impact on individuals and institutions (New Directions for Teaching and Learning No. 57) (pp. 53-63). San Francisco: Jossey-Bass.

Kurfiss, J., \& Boice, R. (1990). Current and desired faculty development practices among POD members. In L. Hilsen (Ed.), To Improve the Academy, Vol. 9. (pp.73-82). Stillwater, OK: New Forums Press and the Professional and Organizational Development Network in Higher Education.

Luna, O., \& Cullen, D. L. (1995). Empowering the faculty: Mentoring redirected and renewed (ASHE-ERIC Higher Education Rep. No. 3). Washington, DC: The George Washington University, School of Education and Human Development.

Merriam, S. B. (1987). Mentoring in higher education: What we know now. Review of Higher Education, 11, 199-210.

Millis, B. J. (1994). Forging the ties that bind: Peer mentoring part-time faculty. In M. A. Wunsch (Ed.), Mentoring revisited: Making an impact on individuals and institutions (New Directions for Teaching and Learning No. 57) (pp. 73-80). San Francisco: Jossey-Bass.

Nichols, R. J., \& Amick, B. T. (1995). The case for instructional mentoring. In E. Neal (Ed.), To Improve the Academy, Vol. 14. (pp.143-155). Stillwater, OK:New Forums Press and the Professional and Organizational Development Network in Higher Education.

Rackin, D. (1992, November). Mentoring new faculty with emeritus faculty. Paper presented at the 12th Annual Lilly Conference on College Teaching, Oxford, OH.

Sandler, B. R. (1993, March 10). Women as mentors: Myths and commandments. The Chronicle of Higher Education, 39, p. B3. 
Sayles-Folks, S., \& King, E. (1994). Building an institutional support system for new faculty through mentoring. International Memoring Association Diversity in Mentoring Proceedings (pp. 271-281). Kalamazoo, MI: Western Michigan University.

Schoenfeld, C., \& Magnan, R. (1994). Mentor in a manual: Climbing the academic ladder to tenure. Madison, WI: Magna.

Seal, R. K. (1993). Resources for developing senior faculty as teachers. In M. J. Finkelstein \& M. W. LaCelle-Peterson (Bds.), Developing senior faculty as teachers (New Directions for Teaching and Learning No. 55) (pp. 99-111). San Francisco: JosseyBass.

Shea, M. A., \& Knoedler, A. S. (1994). Becoming a teacher: From pedagogy to praxis. Journal on Excellence in College Teaching, 5(2), 135-151.

Sorcinelli, M. D. (1992). New and junior faculty stress: Research and responses. In M. D. Sorcinelli \& A. E. Austin (Eds.), Developing new and junior faculty (New Directions for Teaching and Learning No. 50) (pp. 27-37). San Francisco: Jossey-Bass.

Sorcinelli, M. D. (1995). How mentoring programs can improve teaching. In P. Seldin \& Associates (Eds.), Improving college teaching (pp. 125-136). Bolton, MA: Anker.

Weimer, M. (1990). Improving college teaching: Strategies for developing instructional effectiveness. San Francisco: Jossey-Bass.

Wise, W. M. (1967). Who teaches the teachers? In C. B. T. Lee (Ed.), Improving college teaching (pp. 77-89). Washington, DC: American Council on Education.

Wright, W. A., \& O'Neil, M. C. (1994). Teaching improvement practices: New perspectives. In E. Wadsworth (Ed.), To Improve the Academy, Vol. 13. (pp.5-38). Stillwater, OK: New Forums Press and the Professional and Organizational Development Network in Higher Education.

Wright, W. A., \& O'Neil, M. C. (1995). Teaching improvement practices: International perspectives. In W. A. Wright \& Associates (Eds.), Teaching improvement practices: Successful strategies for higher education (pp. 1-57). Bolton, MA: Anker.

Wunsch, M. A. (Ed.). (1994). Mentoring revisited: Making an impact on individuals and institutions. (New Directions for Teaching and Learning No. 57). San Francisco: Jossey-Bass.

Contact:

Milton D. Cox

Teaching Effectiveness Programs

Office for the Advancement of Scholarship and Teaching

Miami University

Oxford, OH 45056

(513) 529-6648 Phone

(513) 529-3762 Fax

cox_milt@msmail.muohio.edu

Milton D. Cox has directed the 1994 Hesburgh award-winning Teaching Scholars Program at Miami University for 18 years. He is founder and director of The 
Lilly Conference On College Teaching and is editor-in-chief of the Journal on Excellence in College Teaching. He teaches mathematics and this year directs his 24th annual National Student Mathematics Conference at Miami. He has served as chair of the Ohio Section of the Mathematical Association of America and as president of Pi Mu Epsilon, the national mathematics honorary society, which awarded him the C.C. MacDuffee Award for meritorious service. 


\section{APPENDIX}

September 4, 1996

To: [Mentor's Name, Department], Mentor, 1996-97 Teaching Scholars Program

From: Milt Cox, University Director for Teaching Effectiveness Programs

Welcome to the Teaching Scholars Program! I'm pleased that you have agreed to serve. [Protégé's Name] is looking forward to working with you this year.

The purpose, description, goals, and objectives of the Program are enclosed.

Let me review with you some insights about past mentoring and our plans for this year.

(1) You may be quite flexible in structuring your Teaching ScholarMentor interaction. Formats have varied in the past from weekly or occasional class observation exchanges to weekly or biweekly meetings over lunch to discuss teaching, research and university politics. There are no rigid guidelines, since we do not wish to stifle "creative mentoring." It is a matter of your two personalities, needs, styles and schedules.

(2) A structured approach with scheduled meetings is best for most mentoring pairs. Robert Boice (1992), in his chapter on "Lessons Learned About Mentoring," indicates three outcomes of interest to us arising from his research on mentoring pairs: (1) frequent nudges to meet regularly helped ensure pair bonds, (2) left to themselves, most mentoring pairs displayed disappointingly narrow styles, and (3) mentors assumed the role of interventionist with reluctance. Read the enclosed article, "Women as Mentors: 
Myths and Commandments", for a nice summary of mentoring pros and cons.

Thus, it's up to you and me to provide the nudges and expand the discussion. The semester can slip away unless you plan your mentoring interaction carefully. Possible activities include visiting or auditing of each other's classes; attending Program seminars together; attending some Lilly Conference sessions; exchanging and discussing videotapes or Small Group Instructional Diagnosis (SGID) visits; and luncheon or informal meetings to discuss teaching, contraries raised in seminars, university politics, and the profession. To prevent narrow styles, try a broad variety of activities. I have enclosed a mentor/protégé meeting log so that you can keep track of your interactions.

(3) You will be invited to attend some of our teaching seminars and other program events throughout the year. In the past, some Mentors have attended several events, while others have been able to attend only a few. We hope you will be able to attend at least one, since your experience and advice are valuable for all the Teaching Scholars as well as your own protégé. However, your major contribution to the Program comes in the one-to-one relationship with your teaching scholar, and that can be time-consuming; hence, you may view the seminars and other programs as optional.

I am enclosing a schedule of first semester events for the teachingscholars so that you know what they are doing in the program. You are invited to attend the events where Mentors are included (see October 10, November 7, November 21-24 and December 12). Please give me advanced notice when you plan to attend so that I can share prerequisite reading material with you and reserve a meal.

This semester's activities for the teaching scholars include a retreat at Berea College. The mission, curriculum and students of Berea College are so different from Miami that this opportunity expands the teaching horizons of our Scholars while also making them more aware of the 
teaching culture at Miami. The scholars will receive extensive literature on Berea and can share it with you; this topic could lead to some interesting discussions.

There is one event this first semester that I especially encourage you to attend with your protégé: the Sixteenth Annual Lilly Conference on College Teaching will be held at the Marcum Conference Center, November 21-24. I will send you a preliminary program later. Last year this was the highlight of the semester, so please mark your calendar and attend some of the sessions. These will provide you with many topics for future discussions. We'll treat you to lunch and dinner at the Conference.

We help the teaching scholars begin a teaching library. You may wish to share and discuss your teaching scholar's book, Teaching Tips, by Wilbert McKeachie of the University of Michigan. This guidebook has been a valuable resource for concise information and bibliographical references to teaching research, techniques and theories. You are welcome to browse and check out this and other books from the Teaching Effectiveness Library in Roudebush 106.

Enclosed is a schedule form, which I ask that you complete and return to me by September. I will schedule a luncheon for all the Mentors at which you will be our guest and during which we will discuss mentoring and answer any questions you have about the Program. If you have any immediate questions, ideas or concerns, please give me a call at 96648. I'll keep you posted as future seminars and events are scheduled.

In summary, try to meet with your protégé at least once every two weeks. Schedule times in advance or this opportunity will quickly slip away. Discuss teaching issues that arise in your classroom exchanges, books or articles you share, and seminars you attend. In some cases, these partnerships have led to joint publications. 
I hope you find your involvement with your Teaching Scholar and the Program to be interesting, productive and rewarding. Thank you, in advance, for serving.

\section{Reference}

Boice, R. (1992). Lessons learned about mentoring. In M. D. Sorcinelli \& A. E. Austin (Eds.), Developing new and junior faculty (New Directions for Teaching and Learning No. 50) (pp. 51-61). San Francisco: Jossey-Bass.

\section{Enclosures:}

Program goals and objectives Brief biographies of Program participants

Schedule form

Calendar of events

Article: Women as Mentors: Myths and Commandments Mentor/Protégé meeting log

cc: [Protégé's Name, Department]

[Department Chair's Name, Department] 